\title{
Feeding Ecology of Juvenile Masu Salmon Oncorhynchus masou in the Coasts of Hokkaido with Special Reference to Stomach Contents
}

\author{
Hiroki Asami and Hirofumi Hayano \\ Hokkaido Fish Hatchery, Kitakashiwagi, Eniwa, Hokkaido 061-14, Japan \\ (Received October 7, 1994)
}

\begin{abstract}
Feeding ecology of juvenile masu salmon, Oncorhynchus masou, collected by commercial set nets, was studied in the coastal waters of Hokkaido between 1991 and 1993. Stomach fullness indices varied among sampling dates and two areas sampled (Japan Sea and Pacific Ocean). The stomach contents of juveniles collected along the coasts of the northern Japan Sea were composed entirely of sand lances (Ammodytes personatus), which were 1/4-1/2 of the body lengths of the juvenile salmon. In contrast, stomach contents of the juveniles collected along the coast of the Pacific Ocean included a variety of organisms, and size ratios of prey to juveniles were lower than those in the northern Japan Sea. The results of comparisons of juvenile stomach contents between the Japan Sea and Pacific Ocean indicate that juvenile masu salmon occupy different ecological niches in the two areas. Production of juveniles in the northern Japan Sea may depend on the abundance of sand lance.
\end{abstract}

Key words: juvenile masu salmon, feeding, sand lance, Hokkaido coasts

Masu salmon Oncorhyncus masou is one of the most important fishes in Hokkaido fisheries and various enhancement efforts have been attempted. Nevertheless, the fishery production of this species is at a low level of 1000 $2000 \mathrm{t} /$ year, about $1-2 \%$ of the total catch of salmonid fishes in Japan." In general, much of the mortality of juvenile anadromous salmonid fishes occurs during emigration from river to ocean. ${ }^{2,3)}$ This period has been called the "critical first summer", 4) and may be important in determining the abundance of returning adults. According to previous studies, juvenile masu salmon are widely distributed in coastal areas, and are most abundant from April to May." The main prey items of juvenile masu salmon in the coastal areas of Honshu are small fishes and crustacean zooplankton. ${ }^{\text {) }}$ Little is known, however, about the early ocean life ecology of this species in Hokkaido. This paper reports on the feeding ecology of juvenile masu salmon in the coastal areas of Hokkaido.

\section{Materials and Methods}

Juvenile masu salmon were collected by commercial set nets in the coastal areas off Rumoi and Shosanbetsu in the northern Japan Sea, and off Erimo in the Pacific Ocean off Hokkaido (Fig. 1). Samples were collected four times from May 13 to June 10, 1991, and seven times from May 25 to June 12, 1992 off Rumoi; four times from May 27 to June 3, 1992 off Shosanbetsu; and three times from June 22 to June 30, 1993 off Erimo. Set nets were usually retrieved in the early morning (7:00) off Rumoi, three times in the early morning $(7: 40)$ and one time in the mid afternoon (15:00) off Shosanbetsu, and two times in the early morning $(5: 00)$ and once in the early afternoon (13:00) off Erimo. After the capture, samples were fixed with $10 \%$ formalin and body weight (nearest $0.01 \mathrm{~g}$ ) and stomach weight $(0.01 \mathrm{~g})$ were measured in the laboratory. The fork lengths $(0.01 \mathrm{~cm})$ of juveniles used in the present study were below $25.00 \mathrm{~cm}$ in maximum size. Condition factors (C.F.) and stomach fullness index (S.F.I.) were calculated as follows:

$$
\begin{gathered}
\text { C.F. = body weight }(\mathrm{g}) / \text { fork length }(\mathrm{cm})^{3} \times 1000 \\
\text { S.F.I. }(\% 0)=\text { stomach contents weight }(\mathrm{g}) / \text { body } \\
\text { weight }(\mathrm{g}) \times 1000
\end{gathered}
$$

Significant differences in mean fork lengths, body weights, and condition factors among three areas were tested by using Duncan's new multiple range test.

Stomach contents of juvenile masu salmon were analyzed by dissecting microscopy. The body lengths of prey fishes in the stomachs were measured as far as possible.

Zooplankton samplings were conducted at St. 1 (30 m depth) and St. 2 (60 m depth) off Rumoi on 12 June and 2 July 1992. Zooplankton were collected from near bottom to surface with a Norpac net $(45 \mathrm{~cm}$ mouth opening and $0.33 \mathrm{~mm}$ in mesh size). The net was towed vertically at a speed of about $0.5 \mathrm{~cm} / \mathrm{s}$. Because a flow-meter was not used in these samplings, water filteration efficiency was assumed to be $100 \%$. After the collection, samples were fixed with $5 \%$ formalin. Samples were divided into two to four subsamples using a plankton splitter ${ }^{6}$ and the number of individuals (inds. $/ \mathrm{m}^{3}$ ) in each category were counted under the dissecting microscopy in a laboratory.

\section{Results}

\section{Biological Data}

The number of juvenile masu salmon collected in the coastal areas was 114 off Rumoi (68 in 1991 and 46 in 1992), 14 off Shosanbetsu and 26 off Erimo (Table 1). Fork length and body weight of juveniles in the coastal areas were about $15.1-18.6 \mathrm{~cm}$ and $40.0-66.6 \mathrm{~g}$, respectively. There were no statistically significant differences in fork lengths, body weights, and condition factors of juvenile masu 


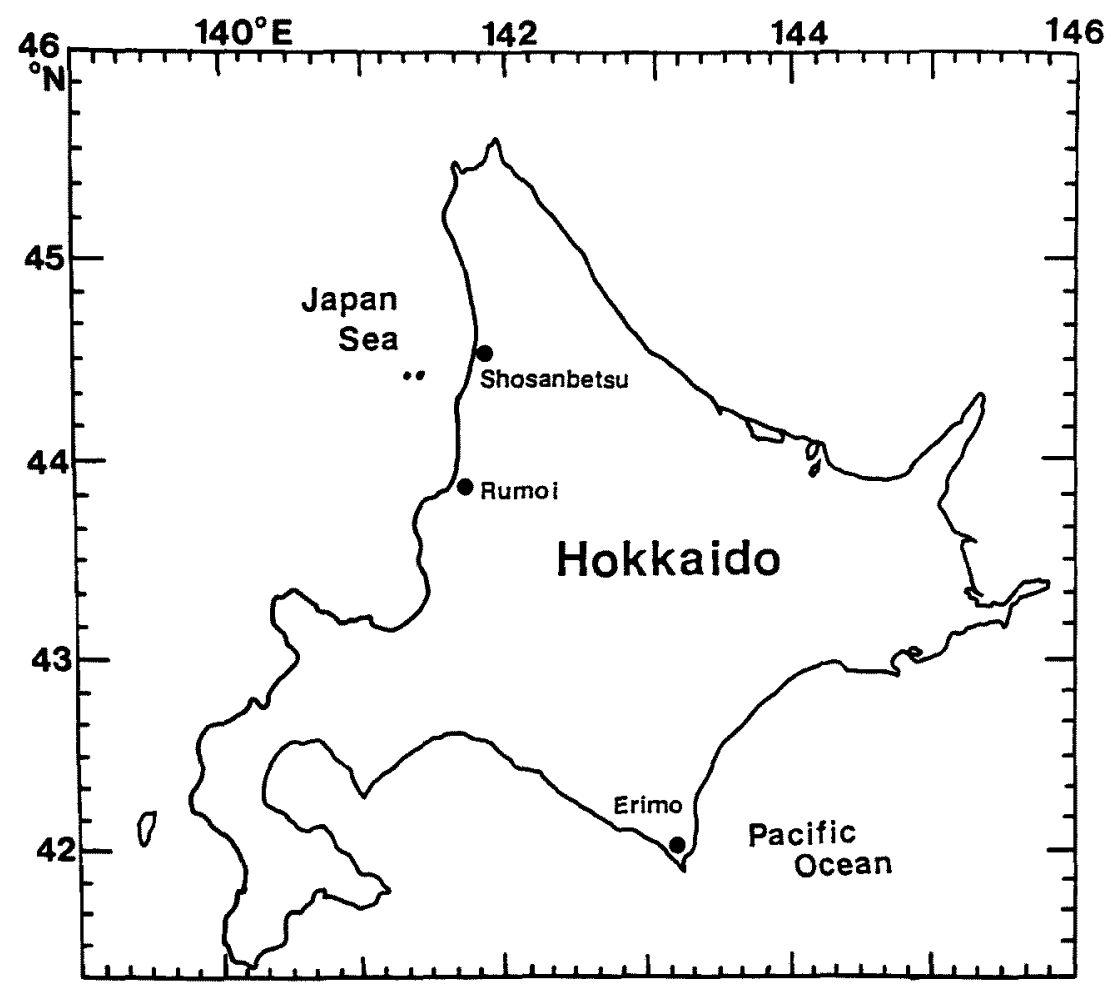

Fig. 1. Areas where juvenile masu salmon were sampled by commercial set nets. Zooplankton samplings were conducted along the coast of Rumoi, northern Japan Sea.

Table 1. Biological data of juveniles in three coastal areas

\begin{tabular}{|c|c|c|c|c|}
\hline \multirow{2}{*}{ Areas } & \multicolumn{3}{|c|}{ Japan Sea } & \multirow{3}{*}{$\begin{array}{c}\text { Pacific Coast } \\
\text { Erimo } \\
1993 \\
6.22-6.30\end{array}$} \\
\hline & \multicolumn{2}{|c|}{ Rumoi } & \multirow{2}{*}{$\begin{array}{c}\text { Shosanbetsu } \\
1992 \\
5.27-6.3\end{array}$} & \\
\hline $\begin{array}{l}\text { Sampling } \\
\text { period }\end{array}$ & $\begin{array}{c}1991 \\
5.13-6.10\end{array}$ & $\begin{array}{c}1992 \\
5.25-6.12\end{array}$ & & \\
\hline No. of individuals & 68 & 46 & 14 & 26 \\
\hline Fork length (cm, mean $\pm \mathrm{SD}$ ) & $16.40 \pm 2.25^{\mathrm{b}}$ & $17.16 \pm 3.66^{\mathrm{ab}}$ & $15.14 \pm 1.02^{\mathrm{c}}$ & $18.57 \pm 1.86^{\mathrm{a}}$ \\
\hline Body weight $(g$, mean $\pm S D)$ & $52.85 \pm 26.86^{\mathrm{a}}$ & $62.23 \pm 45.52^{\mathrm{a}}$ & $39.96 \pm 8.99^{b}$ & $66.55 \pm 21.11^{\mathrm{a}}$ \\
\hline Condition factor (mean $\pm S D$ ) & $11.23 \pm 0.98^{\mathrm{a}}$ & $10.67 \pm 1.15^{\mathrm{a}}$ & $11.35 \pm 0.89^{\mathrm{a}}$ & $10.13 \pm 0.77^{b}$ \\
\hline
\end{tabular}

The values not sharing a common superscript letter are significantly different (Duncan's new multiple range test).

salmon between 1991 and 1992 in samples collected off Rumoi $(p>0.01)$. The mean fork lengths and body weights of juveniles collected off Shosanbetsu were smaller than those of juveniles collected off Rumoi and Erimo $(p<0.01)$. Mean condition factors of juveniles collected at Rumoi and Shosanbetsu were not significantly different $(p>0.01)$. However, the condition factor of juveniles from the coast of Erimo was lower than those of Rumoi or Shosanbetsu (comparison of Rumoi in 1991; $p<0.01$, comparison of Rumoi in 1992; $p<0.05$, comparison of Shosanbetsu; $p<0.01$ ).

\section{Stomach Fullness Index}

Stomach fullness indices varied among individuals and sample date in all three coastal areas (Fig. 2). While some stomachs were empty, very high stomach indices were also found. The values (\%o) ranged from 0.7 to 68.6 in 1991 and from 0.0 to 30.8 in 1992 off Rumoi, 1.1 to 38.1 off Shosanbetsu, and 0.0 to $77.9 \mathrm{off}$ Erimo.

\section{Stomach Contents}

Stomach contents were very simple for juvenile masu salmon collected in both of the two coastal areas in the northern Japan Sea (Table 2). Stomachs of juveniles contained only juvenile sand lance, Ammodytes personatus. No body parts of zooplankton were observed, even in the digested contents. On the other hand, stomachs of juveniles collected in the coastal areas off Erimo of the Pacific Ocean included both fish and large zooplankton. The size ratios of major prey organisms (sand lance) to juvenile masu salmon were almost $1 / 4-1 / 2$ in the northern Japan Sea, and ratios were often lower in the Pacific Ocean (Fig. 3).

\section{Zooplankton in the Coast off Rumoi}

The total density of zooplankton was about 450 inds./ $\mathrm{m}^{3}$ at St. 1 and about 2800 inds. $/ \mathrm{m}^{3}$ at St. 2 in early June (Table 3). Copepoda and appendicularia were predominant at both stations. Crustacean larvae and eggs 


$\begin{array}{cc}\text { Rumoi } & \text { Rumoi } \\ 1991 & 1992\end{array}$

\section{Shosanbetsu 1992}

\section{Erimo 1993}



Fig. 2. Stomach fullness index of juvenile masu salmon in three different coastal areas.

Table 2. Stomach contents of juvenile masu salmon collected by set nets in three different coastal areas

\begin{tabular}{|c|c|c|c|c|}
\hline \multirow{2}{*}{ Areas } & \multicolumn{3}{|c|}{ Japan Sea } & \multirow{3}{*}{$\begin{array}{c}\frac{\text { Pacific Coast }}{\text { Erimo }} \\
1993 \\
6.22-6.30\end{array}$} \\
\hline & \multicolumn{2}{|c|}{ Rumoi } & \multirow{2}{*}{$\frac{\text { Shosanbetsu }}{1992}$} & \\
\hline $\begin{array}{l}\text { Sampling } \\
\text { period }\end{array}$ & $\begin{array}{c}1991 \\
5.13-6.10\end{array}$ & $\begin{array}{c}1992 \\
5.25-6.12\end{array}$ & & \\
\hline \multicolumn{5}{|l|}{ Fishes } \\
\hline Sand lance & 50 & 22 & 9 & 3 \\
\hline Chum salmons & 0 & 0 & 0 & 10 \\
\hline others & 0 & 0 & 0 & 13 \\
\hline \multicolumn{5}{|l|}{ Zooplankton } \\
\hline Copepods & 0 & 0 & 0 & 5 \\
\hline Amphipods & 0 & 0 & 0 & 4 \\
\hline Euphausiids & 0 & 0 & 0 & 2 \\
\hline Megalopa & 0 & 0 & 0 & 8 \\
\hline Digested & 18 & 13 & 5 & 0 \\
\hline Empty & 0 & 11 & 0 & 3 \\
\hline $\begin{array}{l}\text { Juveniles } \\
\text { examined (inds.) }\end{array}$ & 68 & 46 & 14 & 26 \\
\hline
\end{tabular}

The numerical values indicate individual number of juveniles which graze each prey item.

(maybe euphausiids) also dominated at St. 2. In early July, the density of individuals increased to about 1900 inds./ $\mathrm{m}^{3}$ at St. 1 , and decreased to about 1300 inds. $/ \mathrm{m}^{3}$ at St. 2 . Copepoda and appendicularia were predominant at both stations, which was the same as the results in June.

\section{Discussion}

Stomach fullness indices varied among individuals in the three coastal areas (Fig. 2). Set nets were deployed for a period of about 24 hours. Therefore, the times of capture of juveniles may be different, and might have resulted in large differences in stomach fullness indices.

According to some previous studies in Honshu, juvenile masu salmon are intense fish feeders, but large crustaceous zooplankton were also observed in some stomachs. ${ }^{5)}$ The same trends were found in juvenile masu salmon collected off Erimo in the Pacific Ocean, but results from the northern Japan Sea were very different (Table 2). In the Japan Sea off Hokkaido, zooplankton were most abundant from May to June. ") Juvenile of the northern Japan Sea depend mainly on sand lances in spite of the exisistences of zooplankton, as observed in 1992 (Table 3). There is no information on ecology of sand lance in this area.

Condition factors, which are thought to be an index of the nutritional state of juvenile salmon, were higher in fish collected in the northern Japan Sea than in fish collected in the Pacific Ocean (Table 1). This indicates that the northern Japan Sea, where juveniles grazed on sand lance, is a better feeding ground for masu salmon than the Pacific Ocean.

Immature masu salmons ( $>25 \mathrm{~cm}$ in fork length) migrating to Shakotan in the southwestern Japan Sea of Hokkaido ate sand lance, which were almost $1 / 4-1 / 3$ of fork 


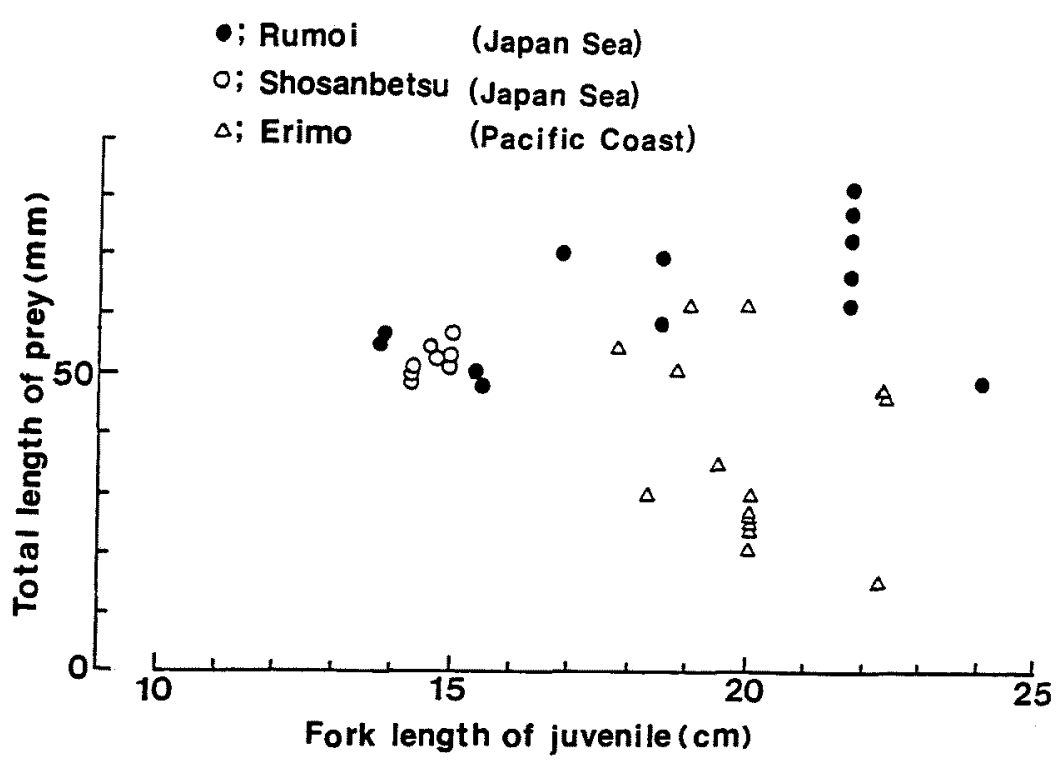

Fig. 3. Relationship between the fork length of juvenile masu salmon and the total length of prey fishes in three different coastal areas. Prey fishes are only sand lances in Rumoi and Shosanbetsu.

Table 3. Total density of zooplankton collected in the coastal waters off Rumoi in the northern Japan Sea in June and July

\begin{tabular}{lrrrrr}
\hline \multirow{2}{*}{ Composition } & \multicolumn{2}{c}{1992.6 .12} & & \multicolumn{2}{c}{1992.7 .2} \\
\cline { 2 - 3 } \cline { 6 - 7 } & \multicolumn{1}{c}{ St. 1 } & \multicolumn{1}{c}{ St. 2 } & & \multicolumn{1}{c}{ St. 1 } & St. 2 \\
\hline Copepoda & 387.6 & 1599.4 & & 856.5 & 587.0 \\
Appendicularia & 28.2 & 392.6 & & 1001.1 & 674.2 \\
Hydrozoa & 5.1 & 10.2 & & 33.9 & 24.9 \\
Amphipoda & 4.0 & 0.0 & & 0.0 & 0.0 \\
Polychaeta & 0.0 & 18.1 & & 0.0 & 0.0 \\
Mysidacea & 0.0 & 2.3 & & 0.0 & 0.0 \\
Crustacean larvae & 4.0 & 218.7 & & 0.0 & 40.0 \\
egg & 5.6 & 525.2 & & 0.0 & 7.9 \\
\hline Total density (inds. $/ \mathrm{m}^{3}$ ) & 434.5 & 2766.5 & & 1891.5 & 1334 \\
\hline
\end{tabular}

length of masu salmon. ${ }^{8)}$ In this study, stomach contents of juvenile masu salmon ( $<25 \mathrm{~cm}$ in fork length) collected in the northern Japan Sea were sand lance, which were 1/ 4-1/2 of fork length of masu salmon (Fig. 3). Masu salmon from juvenile to immature stage are size-selective grazers in the Japan Sea off Hokkaido.

Juvenile masu salmon in the northern Japan Sea occupy the fourth trophic level (assuming sand lance feed mainly on herbivorous zooplankton). ${ }^{9)}$ On the other hand, juvenile masu salmon in the Pacific Ocean often feed at a lower trophic level. The abundance of juvenile sand lance may affect the survival, growth, and migratory behaviour of juvenile masu salmon in the northern Japan Sea off Hokkaido.

Acknowledgments We give our hearty thanks to Mr. N. Sukegawa, chief of Rumoi Salmon Fisheries Organization and member of Shosanbetsu and Erimo Fisheries Cooperation for collecting the samples. We also thank the staff of Fisheries Division of Rumoi Branch Agency of the Hokkaido Government for their help in sampling. We express special thanks to Dr. William G. Pearcy of Oregon State University and Ms. Katherine W. Myers of University of Washington for their comments on this manuscript.

\section{References}

1) H. Mayama: Studies on the freshwater life and propagation technology of masu salmon Oncorhyncus masou (BREVOORT). Sci. Rep. Hokkaido Salmon Hatchery, 46, 1-156 (1992) (in Japanese).

2) R. R. Parker: Marine mortality schedules of pink salmon of the Bella Coola River, Central British Columbia, J. Fish. Res. Bd. Can., 25, 757-794 (1968).

3) N. J. Bax: Early marine mortality of juvenile chum salmon (Oncorhynchus keta) released into Hood Canal, Puget Sound, Washington, in 1980. Can. J. Fish. aquat. Sci., 40, 426-435 (1983).

4) A. C. Hartt: Juvenile salmonids in the ocean ecosystem-the critical first summer, in "Salmonid Ecosystem North Pacific" (ed. by W. T. McNeil and D. C. Himsworth), Oregon State University Press, Corvallis, Oregon, 1980, pp. 25-57.

5) F. Kato: Life histories of masu and amago salmon (Oncorhynchus masou and Oncorhynchus rhodurus), in "Pacific Salmon Life Histories" (ed. by C. Groot and L. Margolis), UBS Press, Vancouver, 1991, pp. 447-520.

6) S. Mododa: Devices of simple plankton apparatus. Mem. Fac. Fish. Hokkaido Univ., 14, 152-162 (1959).

7) M. Kotori: Plankton biomass and productivity in the seas around Hokkaido. Bull. Japan. Soc. Fish. Oceanogr., 45, 49-55 (1984) (in Japanese).

8) F. Sasaki: On the immature masu salmon, Oncorhynchus masou (BREVOORT), migrated to the Shakotan area. Part 3. Stomach contents. Hokusuishigeppo, 40, 227-238 (1983) (in Japanese).

9) H. Sekiguchi, M. Nagoshi, Y. Mori, and Y. Kato: The feeding habits of larvae and juveniles of sand-eel, Ammodytes personatus (GIRARD), an anchovy, Engraulis japonica HOUTTUYN, in Ise Bay. Bull. Fac. Fish, Mie Univ, 1, 33-41 (1974) (in Japanese). 